\title{
Colour removal of the synthetic dye wastewater using Up flow Anaerobic Sludge Blanket Reactor
}

\author{
T.Velayutham ${ }^{1}$ and $\mathrm{N}$ Ashok kumar ${ }^{2}$ \\ Assistant Professore ${ }^{1,2}$, Department of Civil Engineering, FEAT, Annamalai university \\ Annamalai nagar.608002 \\ Email:velayutham.au@gmail.com ${ }^{1}$,ashokviji.2002@.com ${ }^{2}$
}

\begin{abstract}
The colour removal of the synthetic dye wastewater with the addition of glucose as co-substrates using a Up flow Anaerobic Sludge Blanket (UASB) reactor was investigated in the present study. This experiment was conducted under room temperature $\left(30 \pm 2{ }^{\circ} \mathrm{C}\right)$ at varying concentrations $(40 \mathrm{mg} / 1,60 \mathrm{mg} / 1,80 \mathrm{mg} / 1,100 \mathrm{mg} / \mathrm{l}$ , $150 \mathrm{mg} / \mathrm{l}, 200 \mathrm{mg} / \mathrm{l}, 250 \mathrm{mg} / \mathrm{l}$ and $300 \mathrm{mg} / \mathrm{l}$ ) of Congo red synthetic dyeing wastewater, with an Organic Loading Rate (OLR) of 31.2,46.8,62.4,78.2,117.3, 156.4,195.5,238.6 kg COD $/ \mathrm{m}^{3} \mathrm{~d}$ respectively. It was observed at 12 hours HRT, $99.0 \%, 99.0 \%, 98.88 \%, 98.0 \%, 95.10 \%, 92.45 \%$ and $87.9 \%$ efficiency of colour elimination were obtained at $60 \mathrm{mg} / 1,80 \mathrm{mg} / 1.100 \mathrm{mg} / 1,150 \mathrm{mg} / 1,200 \mathrm{mg} / 1,250 \mathrm{mg} / \mathrm{l}$ and $300 \mathrm{mg} / \mathrm{l}$ of Congo red concentration within 10 days. For the above mentioned Organic loading Rate ,the gas production percentage in the anaerobic reactor obtained was $85,84,80,76.9,67.5,56.88,41.85,35.6$ and Volumetric methane productions was 2.95, 2.94, $2.6,2.15,1.88,1.56,1.50 \mathrm{~L} / \mathrm{day}$.
\end{abstract}

Keywords-Aanaerobic digestion; textile dye; neutral pH; COD; biogas

\section{INTRODUCTION}

Textile industries produce highly coloured wastewater with varying composition based on the wet process employed. The treatments of Textile dyeing industrial waste water have become tougher now a day's and new methods for the treatment for such wastewater are frequently being investigated. All over the world, standard regulations for the discharge of industrial wastewater were being updated and enforced, and the need for more effectiveness in wastewater treatment systems is being increased. Because textile dyeing industrial effluents contain numerous types of pollutants, such as dispersants, levelling agents, salts, carriers, acids, alkali and various dyes (Couto, S.R., 2009). The textile dyeing industry consumes huge quantity of water, energy and auxiliary chemicals. In India, the textile dyeing industries likely to discharge approximately 1.5 million litres of effluent per day and the waste water is being released into natural water bodies and agricultural land without any appropriate treatment.

The textile dyeing industry wastewater is rated as the maximum polluting industry among all industrial sectors (Al-Kdasi et al. 2004) by considering the volume of waste generated and the effluent composition. The discharge of dyes and dye removal products becomes a great environmental concern (Chen et al. 2005) because of colour discharged by the textile industry effluent. Dyes are synthetic organics and generally have a complex chemical structure. They are xeno-biotic in biotic environments and hence show persistence to biodegradation in nature. The release of dye compounds into streams and water impounding structures have an adverse impact on photosynthesis of aquatic plants, the carcinogenic nature of these dyes and their break-down products (Padhi, B.S., 2012). Although the available physical and chemical wastewater treatment methodss are fairly effective, they become expensive when applied on a larger field scale. Therefore, biological treatment techniques are considered as a feasible option for waste management, especially for developing nations (Bhatti et al. 1996; Arshad et al. 2011). The biological treatment methods are primarily of two kinds, aerobic process and anaerobic process. Because of huge energy and nutrition input requirements of the aerobic process, comparatively more importance is given to anaerobic digestion. The utilization of anaerobic digestion which is fairly cheaper in operation is certainly the most excellent wastewater treatment alternatives.

The Up flow Anaerobic Sludge Blanket (UASB) reactor was improved by Lettinga and his co-workers in the 1970s and it gets recognition and has been effectively used to treat a variety of biodegradable industrial wastewaters (Bal, A.S. and Dhagat, N.N., 2001). UASB reactors belong to the group of high value efficiency reactors with anaerobic sludge bed.

Excellent settling properties and granular biomass with high methanogenic activity can be obtained in these reactors. The constraints of UASB reactors are related to the wash-out of biomass and volume of sludge. In the present study, textile dyeing effluent wastewater at various concentrations was used. The glucose was utilised as co-substrate with ratio (80:20) 


\section{Available online at www.ijrat.org}

to develop the degradation of synthetic dyewastewater which is recalcitrant in nature. Therefore, the aim of this paper was designed using a single-stage UASB reactor to examine the treatment feasibility of textile dye wastewater operation with the presence of external carbon sources. The co-substrate is an alternative growth substrate which when provided to a bioreactor can improve the degradation of some effluent wastes that cannot support microbial growth alone (Franco-Correa, et al.2010). It has been described that $1000 \mathrm{mg} / \mathrm{L}$ of glucose can increase the colour removal efficiency by using anaerobic microorganisms in a serum bottle (Carliell et al., 1995), and that co-substrates are important for reduction of azo-bond. Generally, the addition of external carbon sources results in greater dye decolourizations rates.

\section{MATERIALS AND METHOD}

\subsection{Biomass}

The anaerobic granular sludge with unidentified microorganisms used in this research was acquired from the anaerobic municipal, sewage sludge treatment plant, Chidambaram municipality, Tamilnadu, India. Granular sludge was clearly washed, filtered through a fine mesh ASTM 16.to remove the all unwanted content, before loading. By using standard methods, volatile suspended solids content of the sludge was found to be $60,000 \mathrm{mg} / \mathrm{L}-1$.

\subsection{Composition of synthetic dye wastewater}

The initial composition of the synthetic dye wastewater contained Congo red at various concentrations of $40 \mathrm{mg} / 1,60 \mathrm{mg} / \mathrm{l}, 80 \mathrm{mg} / 1.100 \mathrm{mg} / \mathrm{l}$, $150 \mathrm{mg} / \mathrm{l}, 200 \mathrm{mg} / \mathrm{l}, 250 \mathrm{mg} / \mathrm{l}$ and $300 \mathrm{mg} / \mathrm{l}$, growth media and glucose $(80: 20)$. The growth media was made of $\mathrm{NH}_{4} \mathrm{Cl}, 400 ; \mathrm{MgSO}_{4} \cdot 7 \mathrm{H} 2 \mathrm{O}, 400 ; \mathrm{KCl}, 400$; $\mathrm{Na}_{2} \mathrm{~S} \bullet 9 \mathrm{H}_{2} \mathrm{O}, 300 ;\left(\mathrm{NH}_{4}\right) 2 \mathrm{HPO}_{4}, 80 ; \mathrm{CaCl}_{2} \bullet 2 \mathrm{H}_{2} \mathrm{O}, 50$; $\mathrm{FeCl}_{3} \bullet 4 \mathrm{H}_{2} \mathrm{O}, 40 ; \mathrm{CoCl}_{2} \bullet 6 \mathrm{H}_{2} \mathrm{O}, 10 ; \mathrm{KI}, 10 ;\left(\mathrm{NaPO}_{3}\right) 6$, 10; lcysteine, $10 ; \mathrm{AlCl}_{3} \bullet 6 \mathrm{H}_{2} \mathrm{O}, 0.5 ; \mathrm{MnCl}_{2} \bullet 4 \mathrm{H}_{2} \mathrm{O}, 0.5$; $\mathrm{CuCl}_{2}, 0.5 ; \mathrm{ZnCl}_{2}, 0.5 ; \mathrm{NH}_{4} \mathrm{VO}^{3}, 0.5 ; \mathrm{NaMO}_{4} \cdot 2 \mathrm{H}_{2} \mathrm{O}$, $0.5 ; \mathrm{H}_{3} \mathrm{BO}_{3}, 0.5 ; \mathrm{NiCl}_{2} \bullet 6 \mathrm{H}_{2} \mathrm{O}, 0.5 ; \mathrm{NaWO}_{4} \cdot 2 \mathrm{H}_{2} \mathrm{O}, 0.5$, and $\mathrm{Na}_{2} \mathrm{SeO}_{3}, 0.5$ (mg/L) (Speece 1996). The alkalinity and $\mathrm{pH}$ were adjusted by adding $5 \mathrm{M} \mathrm{NaOH}$.

\subsection{Experimental setup}

To study the colour removal efficiency and performance characteristics of UASB reactor, a hybrid combined UASB reactor was fabricated. (Fig. 1). The acidogenic and methanogenic reactors were fabricated with combined single reactors. The reactor $(100 \mathrm{~mm}$ internal diameter and height $1850 \mathrm{~mm}$ ) was made up of plexi-glass with effective volume of $14 \mathrm{~L}$. Sampling, inlet, outlet and gas collection ports were provided at the reactor. The Gas-Liquid-Solid Separator (GLSS) was provided at top of the reactor, and it is made up of an inverted conical funnel at top of the water column for the separation and collection of biogas. In addition to the GLSS arrangement, a packed medium consisting of a Dry fallen seeds of Casuarina equisetifolia, with a surface area of $1000 \mathrm{~mm}^{2}$ and void ratio $89 \%$ has been provided for a height of $250 \mathrm{~mm}$ located at $1250 \mathrm{~mm}$ from the bottom of the reactor. These seeds will retain the biomass in addition to give a polishing effect to the effluent. As soon as the gas entrapped inside, the granules was released, sludge granules trapped in GLSS and the packed media will return to the reactor.

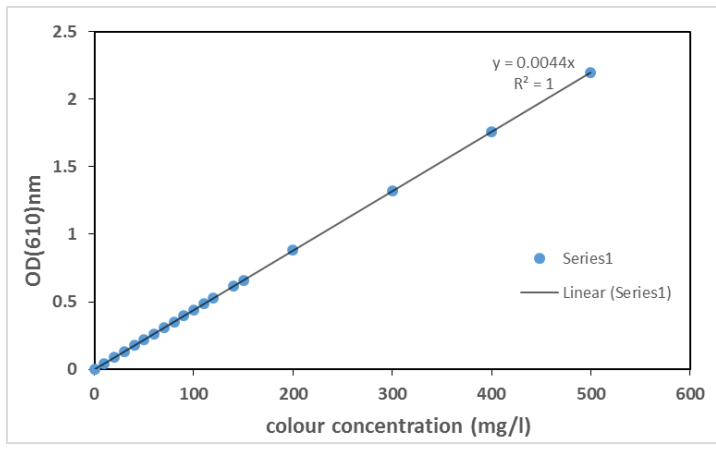

Fig. 1. Standard graph for different dye concentration and (OD)values.

Biogas generated was measured using water displacement method. The studies were conducted after stabilizing the reactor, under the steady state conditions. At steady state the rate of change of inflow to outflow does not change with time and also stable in COD removal and the value of VFA/alkalinity ratio as less than 0.4 shows the steady state condition. The experiment was conducted at room temperature $\left(30 \pm 2^{\circ} \mathrm{C}\right)$ with different concentrations ( $40 \mathrm{mg} / 1,60$ $\mathrm{mg} / 1,80 \mathrm{mg} / 1.100 \mathrm{mg} / 1,150 \mathrm{mg} / \mathrm{l}, 200 \mathrm{mg} / 1,250 \mathrm{mg} / \mathrm{l}$ and $300 \mathrm{mg} / \mathrm{l})$ of synthetic textile dyeing wastewater, with an Organic Loading Rate (OLR) of 31.2,46.8,62.4,78.2,117.3,156.4,195.5,238.6 gCOD/m ${ }^{3}$ $\mathrm{d}$ respectively. According to literature and technical reports (Alaton et al. 2008), the dye concentration of the textile industries varies from 10 to $200 \mathrm{mg} / \mathrm{L} \mathrm{It}$ was also reported, that the high concentrated dye was the more difficult to treat.

\subsection{Analytical procedures}

The influent and effluent samples were analysed for $\mathrm{pH}, \mathrm{COD}$ and colour removal, VFA and alkalinity as per Standard Methods for Examination of Water and Wastewater (APHA 2005). Colour removal was assessed by observing the Optical Density (OD) of the samples using UV-vis spectrophotometer (HITACHI U2001) at $610 \mathrm{~nm}$. A standard graph was plotted with different concentration of synthetic dye as shown in fig.1. Compare with OD value the removal concentration was obtained. COD was observed by using closed reflux titrimetric method. VFA and 


\section{E-ISSN: 2321-9637 \\ Available online at www.ijrat.org}

Alkalinity was also measured by titrimetric method. All samples were filtered through $0.45 \mathrm{~mm}$ filters to remove suspended matters before analysis.

\section{RESULTS AND DISCUSSION}

An upflow anaerobic sludge blanket (UASB) reactor was employed to treat wastewater that contained Congo red at different concentration and continuously stirred by using stirrer at constant speed (rpm). The investigation was carried to find out the effect on the colour removal by constant Hydraulic Retention Time (HRT), OLR, Sludge Retention Time (SRT), and pH.

\subsection{Start-up period}

The main aim of the start-up period was to acquire biofilm formation on the support material. In the present work, Granular sludge of mixed anaerobic cultures was used. The feed contained dye, glucose and growth medium was considered as a feed, during the start-up period. The growth medium contained all the necessary nutrients for the growth of anaerobic microorganism. By keeping the influent COD constant at $500 \mathrm{mg} / \mathrm{l}$, the COD loading was gradually increased by increasing the feed rate during the start- up period. During the start-up period of the reactor, COD loading was gradually raised by increasing the feed rate. while keeping the influent COD constant . The initial dye concentration in the OLR was $15.6 \mathrm{mg} / \mathrm{l}$ and the remaining COD was supplied by glucose at constant ratios (80:20) and growth media (GM).Moreover, $\mathrm{NH}_{4} \mathrm{Cl}$ quantity was steadily increased in $\mathrm{GM}$ to achieve high initial $\mathrm{C} / \mathrm{N}$ ratios during the start-up period to stimulate extracellular polymer production, which supports microorganism attachment on solid surface.

\subsection{Colour removal in a $U A S B$ reactor}

The colour removal efficiency were investigated by different concentration $(60 \mathrm{mg} / 1,80 \mathrm{mg} / 1.100 \mathrm{mg} / \mathrm{l}, 150$ $\mathrm{mg} / 1,200 \mathrm{mg} / \mathrm{l}, 250 \mathrm{mg} / \mathrm{l}$ and $300 \mathrm{mg} / \mathrm{l}$ ) of synthetic dye waste water at an constant HRT12 hours. The consequence of concentration of synthetic dye at different anaerobic stages on the colour removal efficiency of the reactor is shown in Figure (2).At 12 hours HRT $99.0 \%, 99.0 \%, 98.88 \%, 98.0 \%, 95.10 \%$, $92.45 \%$ and $87.9 \%$ colour removal efficiencies were obtained at $60 \mathrm{mg} / 1,80 \mathrm{mg} / 1.100 \mathrm{mg} / 1$, $150 \mathrm{mg} / \mathrm{l}, 200$ $\mathrm{mg} / \mathrm{l}, 250 \mathrm{mg} / \mathrm{l}$ and $300 \mathrm{mg} / \mathrm{lof}$ Congo red concentration at the end of 10 days. As seen from Figure. 2 Colour removal decreased due to increase in dye concentration. It is obvious that the colour removal efficiency of the reactor was adversely affected from this higher dye concentration change in the influent.

Initially the metabolism activity was not affected due to the presence of various types of textile dyes at low concentrations in the influent, Where as it may affect the metabolism due to only of high concentration.
Figure.3. shows the influent and effluent of Dye concentration at $300 \mathrm{mg} / \mathrm{l}$.

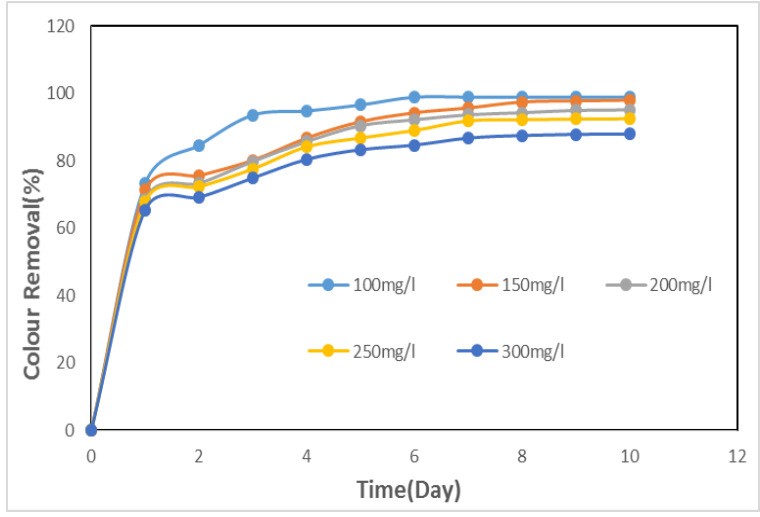

Fig. 2. colour removal(\%) at differentDye concentration.

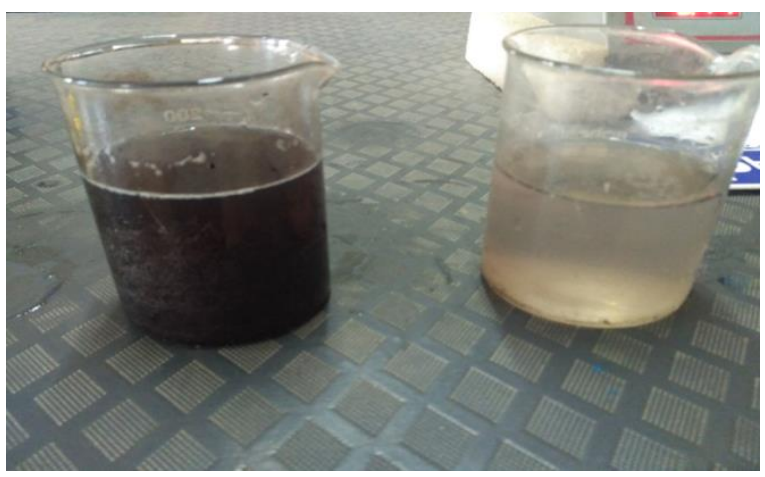

Fig.3 Influent and effluent of Dye concentration at $300 \mathrm{mg} / \mathrm{l}$.

The efficiency was reduced because of high concentration of the dye which may bind over the surface of the sludge granule. Senthilkumar et al.(2009) concluded that the colour removal efficiency from textile dying wastewater using bench scale UASB reactor was 81.0-96.0\%with 17 HRT . Işik and Sponza. (2004). Carliell et al.(1995) and RazoFlores et al. (1997) reported that $90.0 \%$ of colour removal of reactive and azo dyes using anaerobic methane forming bacteria. Thus the present process is more efficient in colour removal by using co-substrate glucose (80:20). Earlier studies with UASB reactors also indicated colour removal efficiency decrease at high dye concentration. Firmino et al. (2010) also found a colour removal efficiency decrease from $92 \%$ to $85 \%$ when the Acid Orange 7 dye concentration increased from $60 \mathrm{mg} / \mathrm{L}$ to $300 \mathrm{mg} / \mathrm{L}$ in a UASB reactor operated at a HRT of $24 \mathrm{~h}$ and supplemented with $1.8 \mathrm{~g} \mathrm{COD} / \mathrm{L}$ of acetate. Thus the present process is efficient in colour removal by using glucose as a cosubstrate at HRT of 12 hwithin10 days. 


\section{Available online at www.ijrat.org}

\subsection{The effect of organic loading rate on Biogas production and colour removal efficiency}

The organic load also changed in the anaerobic reactor depending on the dye concentration, When the dye concentration was increased from 60 $\mathrm{mg} / 1,80 \mathrm{mg} / \mathrm{l} .100 \mathrm{mg} / 1,150 \mathrm{mg} / 1,200 \mathrm{mg} / 1,250 \mathrm{mg} / \mathrm{l}$ and $300 \mathrm{mg} / \mathrm{l}$.Depending upon the increase in the dye load, the colour removal efficiency decreased from $99.0 \%$ to $87.9 \%$. It was concluded from this result that colour removal was negatively affected by dye load. The biogas production percentage also decreased with the increase of OLR (Figure 4). The acidification phase was more active while the OLR was high. This may be due to the negative effect of the high organic load on the activity of methanogenic bacteria. The Biogas production percentage in the anaerobic reactor was $85,84,, 80,76.9,67.5,, 56.88,41.85,35.6$, while the dye organic load was $31.2,46.8,62.4,78.2,117.3$, $156.4,195.5,238.6 \quad \mathrm{gCOD} / \mathrm{m}^{3} \mathrm{~d} \quad$ respectively. Volumetric biogas productions were 2.95, 2.94, 2.6, $2.15,1.88,1.56$ and $1.50 \mathrm{~L} /$ day for the above mentioned organic loads, respectively.

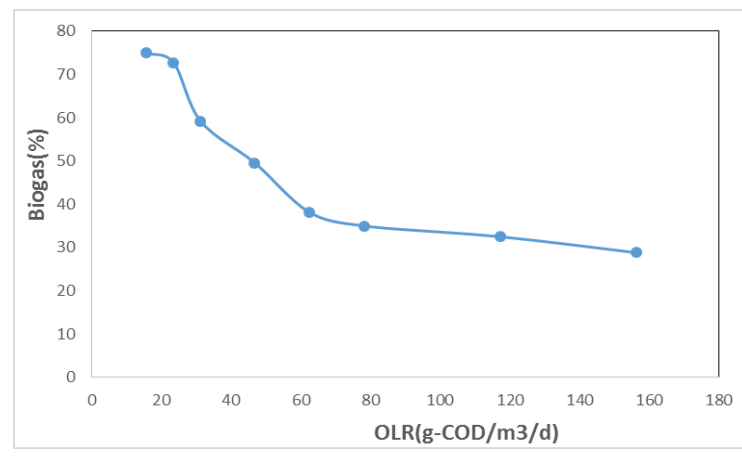

Figure 4. Amount of biogas(\%) production for different dye concentration

The biogas generation is directly related to type of substrate given as feed to the reactor. The biogas production $(2.95, \mathrm{~L} / \mathrm{d})$ was high in OLR31.2 $\mathrm{g}$ $\mathrm{COD} / \mathrm{m} 3 . \mathrm{d}$, and rapidly decreases $(1.5 \mathrm{~L} / \mathrm{d})$ at the high OLR , this due to inhibitory effect of textile dyeing wastewater. Senthil kumar et al(2009) obtained a high biogas production of $312 \mathrm{~L}$ /day at 286 Volume of reactor by conversion treating real textile dyeing wastewater and sago wastewater using pilot scale twophase UASB reactor.

\section{CONCLUSION}

From the results, that for eco-friendly and sustainable treatment system for textile dyeing effluent, with glucose as a co-substrate, which produces very less organic sludge and hence it was concluded that UASB reactor could be a very feasible alternative. The maximum colour removal efficiency achieved was $87.9 \%$ with $12 \mathrm{~h} \mathrm{HRT}$ at $300 \mathrm{mg} / \mathrm{l}$ dye concentration with in 10days. The biogas production was decreased from $2.95 \mathrm{~L} / \mathrm{d}$ to $1.5 \mathrm{~L} / \mathrm{d}$ when dye concentration was increased from $60 \mathrm{mg} / \mathrm{l}$ to $300 \mathrm{mg} / \mathrm{l}$.

\section{REFERENCES}

[1] Couto, S.R., 2009. Dye removal by immobilised fungi. Biotechnology advances, 27(3), pp.227235.

[2] Al-Kdasi.A., Idris.A., Saed.K., and Guan.C.T.,2004,Treatment of textile waste water by advanced Oxidation processes- a review. Globalnest: the Int.J,6(3),pp.222-230.

[3] Chen.X, Shen.Z., Zhu.X., Fan.Y. and Wang.W.,2005Advanced treatment of textile wastewater for reuse using electrochemical oxidation and membrane filtration Water Sa.31(1),pp.127-132.

[4] Padhi.B.S.,2012. Pollution due to synthetic dyes toxicity \& carcinogenicity studies and remediation. International Journal of Environmental Sciences, 3(3), p.940.

[5] Bhatti.Z.I., Furukawa, K. and Fujita, M., 1996. Feasibility of methanolic waste treatment in UASB reactors. Water Research, 30(11), pp.25592568.

[6] Arshad.A., Hashim, N.H., Kashif, A.K. and Bashir, A., 2011. Assessment of the Treatment of Textile Mill Effluent Using UASB Reactor. ASEAN Journal on Science and Technology for Development, 28(2), pp.139-150.

[7] Bal.A.S., and Dhagat, N.N., 2001. Upflow anaerobic sludge blanket reactor a review. Indian journal of environmental health, 43(2), pp.1-82.

[8] Carliel., C.M., Barclay, S.J., Naidoo, N., Buckley, C.A., Mulholland, D.A. and Senior, E., 1995. Microbial decolourisation of a reactive azo dye under anaerobic conditions. WATER SAPRETORIA-, 21, pp.61-61.

[9] Franco-Correa, M., Quintana, A., Duque, C., Suarez, C., Rodríguez, M.X. and Barea, J.M., 2010. Evaluation of actinomycete strains for key traits related with plant growth promotion and mycorrhiza helping activities. Applied soil ecology, 45(3), pp.209-217.

[10] Speece, R.E., 1996. Anaerobic biotechnology for industrial wastewaters. In Anaerobic biotechnology for industrial wastewaters

[11] Arslan-Alaton, I., Gursoy, B.H. and Schmidt, J.E., 2008. Advanced oxidation of acid and reactive dyes: Effect of Fenton treatment on aerobic, anoxic and anaerobic processes. Dyes and Pigments, 78(2), pp.117-130.

[12] Senthilkumar, M., Arutchelvan, V., Kanakasabai, V., Venkatesh, K.R. and Nagarajan, S., 2009. Biomineralisation of dye waste in a two-phase hybrid UASB reactor using starch effluent as a co-substrate. International Journal of Environment and Waste Management, 3(3-4), pp.354-365. 
International Journal of Research in Advent Technology, Vol.7, No.2, February 2019 E-ISSN: 2321-9637

Available online at www.ijrat.org

[13] Işik,M.and Sponza, $\quad$ D.T., 2004. Anaerobic/aerobic sequential treatment of a cotton textile mill wastewater. Journal of Chemical Technology \& Biotechnology, 79(11), pp.1268-1274.

[14] Razo-Flores, E., Luijten, M., Donlon, B.A., Lettinga, G. and Field, J.A., 1997. Complete biodegradation of the azo dye azodisalicylate under anaerobic conditions. Environmental science \& technology, 31(7), pp.2098-2103.

[15] Firmino, P.I.M., da Silva, M.E.R., Cervantes, F.J. And dos Santos,A.B.,2010.Colour removal of dyes from synthetic and real textile wastewaters in one-and two -stage anaerobic systems. Bioresource Technology, 101(20), pp.773-779. 